\title{
Pengaruh Keputusan Pendanaan, Keputusan Investasi, Kebijakan Dividen, Dan Arus Kas Bebas Terhadap Nilai Perusahaan
}

Financial Decisions and Company Value

\author{
Muhammad Fadly Bahrun, Tifah, Amrie Firmansyah \\ Politeknik Keuangan Negara STAN \\ Tangerang Selatan, Indonesia \\ E-mail: fadlybahrun@gmail.com, tifahtifaah@gmail.com, amrie@pknstan.ac.id
}

E-mail: fadlybahrun@gmail.com, tifahtifaah@gmail.com, amrie@pknstan.ac.id

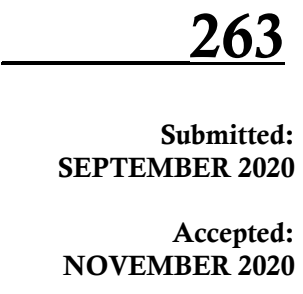

\begin{abstract}
This study examines the effect of funding decisions, investment decisions, dividend policies, and free cash flow on firm value. The samples used in this study are consumer goods industry companies listed on the Indonesia Stock Exchange (IDX) during 2016-2019. Based on purposive sampling, the selected sample is 34 companies, so that the total sample is 136 observations. Hypothesis testing is carried out using multiple linear regression analysis of panel data. The test results show that funding decisions positively affect firm value, while investment decisions do not affect firm value. This study also shows that dividend policy and free cash flow have a negative effect on firm value.
\end{abstract}

Keywords: cash flow; dividend; firm value; funding; investment

\section{PENDAHULUAN}

Salah satu tujuan pendirian perusahaan adalah untuk meningkatkan kesejahteraan para stakeholder. Tujuan tersebut dapat dicapai dengan cara mengoptimalkan nilai perusahaan. Memaksimalkan nilai perusahaan sangat penting artinya bagi perusahaan karena dengan memaksimalkan nilai perusahaan berarti memaksimalkan tujuan utama perusahaan (Ayem \& Tia, 2019). Nilai perusahaan pada dasarnya dapat dilihat dari beberapa sudut pandang, salah satunya adalah harga saham perusahaan (Setiawan et al., 2019).

Pergerakan harga saham dapat kita ketahui melalui indeks pasar saham. Saat ini terdapat 34 indeks yang tercatat di Bursa Efek Indonesia (BEI). Indeks Harga Saham Gabungan (IHSG) merupakan salah satu indeks pasar saham yang digunakan oleh BEI. IHSG mencakup pergerakan harga seluruh saham yang tercatat di Papan Utama dan Papan Pengembangan BEI. IHSG dihitung dengan menggunakan metode Market Capitalization Weighted atau rata-rata tertimbang nilai pasar saham yang tercatat. Perhitungan IHSG dilakukan setelah penutupan perdagangan setiap harinya. Tabel 1 berikut ini menunjukkan indeks pasar saham berdasarkan perhitungan IHSG pada tahun 2014 sampai dengan tahun 2019.

Tabel 1 Indeks Pasar Saham Berdasarkan IHSG Tahun 2014 s.d. 2019

\begin{tabular}{cccc}
\hline Tahun & Nilai IHSG & Tahun & Nilai IHSG \\
\hline 2014 & $5.226,947$ & 2017 & $6.355,654$ \\
2015 & $4.593,008$ & 2018 & $6.194,498$ \\
2016 & $5.296,711$ & 2019 & $6.299,539$ \\
\hline
\end{tabular}

Sumber: Diolah dari Laporan Statistik Tahunan BEI Tahun 2019

Dari Tabel 1 di atas dapat kita lihat adanya penurunan pada tahun 2015 sebesar $12,13 \%$. Penurunan tersebut dapat diakibatkan oleh beberapa faktor. Kenaikan suku bunga bank sentral Amerika Serikat (AS) membuat investor asing mengalihkan sebagian

\section{JIAKES}

Jurnal Ilmiah Akuntansi Kesatuan Vol. 8 No. 3, 2020 pg. 263-276
IBI Kesatuan IBI Kesatuan
ISSN $2337-7852$ E-ISSN 2721 - 3048 
Financial Decisions and Company Value

264 dananya keluar dari instrumen portofolio di Indonesia yang ditandai dengan nilai jual bersih dana investor asing di pasar modal domestik sebesar Rp22,55 triliun (Jefriando, 2015). Pada tahun 2018 juga terjadi penurunan walaupun tidak sebesar pada tahun 2015 , yaitu sebesar 2,54\%. Penurunan indeks ini tidak bisa dilepaskan dari sejumlah katalis negatif baik dari dalam negeri seperti pertumbuhan ekonomi Indonesia yang belum beranjak dari 5\%, depresiasi nilai tukar rupiah, defisit neraca perdagangan, hingga sentimen luar negeri seperti perang dagang dan kenaikan Fed Fund Rate (FFR) bank sentral AS (Saleh, 2018). Fluktuasi yang terjadi dapat diartikan secara tidak langsung bahwa nilai perusahaan yang terdaftar pada indeks Papan Utama di BEI juga demikian. Walaupun begitu, nilai IHSG secara keseluruhan menunjukkan peningkatan, sehingga perusahaan setidaknya harus meningkatkan nilai perusahaannya mengikuti peningkatan indeks pasar saham. Selanjutnya, dengan begitu perusahaan dapat bersaing di pasar saham.

Rachman et al. (2015) berpendapat bahwa nilai perusahaan akan menggambarkan baik buruknya pengelolaan perusahaan yang dilakukan oleh manajemen sehingga diperlukan sinergi yang baik antara pemegang saham dan juga manajemen agar optimalisasi nilai perusahaan dapat dilakukan secara efektif. Terdapat beberapa faktor yang memengaruhi nilai dari suatu perusahaan namun belum ditemukan faktor yang benar-benar memengaruhi nilai perusahaan. Untuk menentukan faktor yang paling berpengaruh terhadap nilai perusahaan, telah banyak dilakukan penelitian terkait dengan nilai perusahaan terutama terkait dengan hubungan antar keputusan keuangan dan juga arus kas bebas (free cash flow). Keputusan keuangan tersebut terdiri atas keputusan pendanaan, keputusan investasi, dan keputusan dividen. Dimana dengan mengoptimalkan ketiga keputusan tersebut dianggap dapat memaksimalkan nilai perusahaan, dengan begitu kesejahteraan para stakeholder juga meningkat. Sedangkan di dalam teori/prinsip manajemen keuangan, arus kas bebas jauh lebih penting nilainya dibandingkan dengan profitabilitas perusahaan.

Keputusan pendanaan adalah sebuah keputusan mengenai bagaimana perusahaan mencari dana dalam membiayai investasi dan juga bagaimana perusahaan menentukan komposisi sumber pendanaan. Sumber pendanaan perusahaan dapat diperoleh baik dari internal maupun eksternal perusahaan. Pendanaan yang berasal dari internal perusahaan yaitu laba ditahan sedangkan pendanaan yang berasal eksternal perusahaan yaitu penerbitan utang atau saham. Suatu kombinasi yang optimal atas penentuan pendanaan tersebut sangat penting karena diharapkan dapat meningkatkan nilai perusahaan. Menentukan sumber pendanaan bukanlah hal yang mudah untuk diputuskan. Banyak faktor yang menjadi pertimbangan perusahaan dalam menentukan sumber pendanaan mereka. Mulai dari aspek perpajakan hingga potensi kebangkrutan. Perusahaan yang didanai dari utang akan membayar pajak yang lebih kecil dibandingkan perusahaan yang didanai dari penerbitan saham dikarenakan bunga pinjaman yang dibayarkan kepada kreditur merupakan tax deductible sehingga akan mengurangi jumlah pajak yang harus dibayarkan oleh perusahaan. Di sisi lain, dividen yang dibayarkan kepada pemegang saham merupakan non-tax deductible sehingga tidak dapat dimasukkan ke dalam komponen pengurang pajak. Sumber pendanaan dari penerbitan utang juga memiliki efek negatif, dimana apabila perusahaan gagal membayar bunga atau pokok utang pada waktu yang telah disepakati bersama kreditur maka kreditur dapat mengajukan perusahaan untuk dipailitkan. Di sisi lain, apabila perusahaan tidak membayar dividen kepada para pemegang saham, perusahaan tidak akan terancam bangkrut. Adapun penelitian terhadap pengaruh keputusan pendanaan terhadap nilai perusahaan telah banyak dilakukan sebelumnya namun masih terdapat inkonsistensi hasil penelitian. Yuliani et al. (2013) dan Sudiarto (2016) menyatakan bahwa keputusan pendanaan tidak memiliki pengaruh yang signifikan terhadap nilai perusahaan sedangkan Rinnaya et al. (2016) dan Sartini \& Purbawangsa (2014) menyatakan bahwa keputusan pendanaan memiliki pengaruh positif dan signifikan terhadap nilai perusahaan sementera penelitian lain yang dilakukan oleh Murni et al. (2019) menyatakan bahwa keputusan pendanaan memiliki efek negatif signifikan terhadap nilai perusahaan. Dengan masih terdapatnya 
inkonsistensi hasil penelitian sebelumnya ditambah dengan dampak dari penentuan sumber pendanaan yang sangat memengaruhi kelangsungan hidup perusahaan membuat keputusan pendanaan menarik untuk diteliti lebih lanjut.

Faktor lain yang dapat memengaruhi nilai perusahaan adalah investasi. Keputusan investasi yang tepat akan menghasilkan kinerja yang optimal (Arizki et al., 2019). Semakin banyak perusahaan melakukan investasi yang tepat maka akan semakin optimal pula kinerja perusahaan. Disisi lain, semakin perusahaan ingin menambah investasinya maka akan semakin banyak pula dana yang dibutuhkan. Perusahaan harus memikirkan struktur modal yang akan digunakan apakah bersumber dari pendanaan internal atau eksternal. Selain itu perusahaan juga harus menentukan proporsi utang maupun modal sendiri yang akan digunakan sebab hal ini akan menentukan cost of capital yang akan menjadi dasar penentuan required return yang diinginkan oleh investor.

Memilih investasi yang menguntungkan bukanlah hal yang mudah dan butuh beberapa pertimbangan dikarenakan keputusan investasi yang hanya berfokus pada informasi finansial saja tidak akan menjamin bahwa keputusan investasi yang dilakukan telah tepat (Devi et al., 2017). Investasi yang paling menguntungkan dapat dilihat dari berbagai sisi, misalnya tingkat pengembalian yang tinggi, waktu pengembalian yang cepat, biaya yang paling rendah, dan risiko yang seminimal mungkin. Adapun penelitian terhadap pengaruh keputusan investasi terhadap nilai perusahaan telah banyak dilakukan sebelumnya namun masih terdapat inkonsistensi hasil penelitian. Dewi et al. (2019) dan Mutmainnah et al. (2019) menyatakan bahwa keputusan investasi memiliki efek positif signifikan terhadap nilai perusahaan sedangkan Rinnaya et al. (2016) dan Arizki et al. (2019) menyatakan bahwa keputusan investasi tidak berpengaruh terhadap nilai perusahaan. Dengan masih terdapatnya inkonsistensi hasil penelitian sebelumnya ditambah dengan pentingnya keputusan investasi yang tepat untuk menghasilkan kinerja yang optimal membuat keputusan investasi menarik untuk diteliti lebih lanjut.

Selain keputusan pendanaan dan investasi, kebijakan dividen juga merupakan faktor yang dapat memengaruhi nilai perusahaan. Keuntungan yang diperoleh oleh perusahaan tidak semata-mata hanya untuk dibagikan sebagai dividen. Dalam keputusan pembagian dividen perlu dipertimbangkan kelangsungan hidup dan pertumbuhan perusahaan. Untuk itu, laba yang diperoleh seringkali tidak seluruhnya dibagikan dalam bentuk dividen akan tetapi ada yang disisihkan untuk diinvestasikan kembali. Dalam penentuan jumlah pembagian dividen, perusahaan juga akan mempertimbangkan kemampuan jangka panjang perusahaan dalam membayarkan dividen. Perusahaan harus menetapkan jumlah dividen yang mampu memuaskan investor dan juga tidak memberatkan cash flow perusahaan. Hal ini penting dilakukan agar para investor tidak kehilangan kepercayaan terhadap perusahaan. Apabila perusahaan membagikan dividen yang besar pada tahun ini lalu tahun depan kekurangan kas sehingga harus mengurangi jumlah dividennya, maka akan membuat citra perusahaan menjadi buruk di mata investornya. sebaliknya, apabila perusahaan memilih untuk "main aman" dengan membagikan dividen dalam jumlah kecil, maka investor akan berpikir bahwa perusahaan ini tidaklah menguntungkan sehingga para investor akan beralih ke perusahaan yang membagikan lebih banyak dividen. Adapun penelitian terhadap pengaruh kebijakan dividen terhadap nilai perusahaan telah banyak dilakukan sebelumnya namun masih terdapat inkonsistensi hasil penelitian. Arizki et al. (2019) dan Mutmainnah et al. (2019) menyatakan bahwa kebijakan dividen memiliki efek positif signifikan terhadap nilai perusahaan sedangkan menurut Ayem \& Tia (2019) kebijakan dividen tidak memiliki pengaruh yang signifikan terhadap nilai perusahaan. Dengan masih terdapatnya inkonsistensi hasil penelitian sebelumnya ditambah dengan pentingnya penentuan jumlah pembagian dividen membuat penelitian terkait keputusan dividen menarik untuk diteliti lebih lanjut.

Selain tiga keputusan keuangan diatas, hal lain yang tidak kalah penting untuk mengukur nilai perusahaan adalah seberapa besar arus kas bebas yang dimiliki oleh perusahaan tersebut. Semakin banyak arus kas bebas pada suatu perusahaan maka kinerja perusahaan tersebut semakin baik (Feriani \& Amanah, 2017). Menurut prinsip manajemen keuangan, arus kas bebas memiliki peran yang penting pada perusahaan
Financial Decisions and Company Value

265 
Financial Decisions and Company Value bahkan lebih penting dibandingkan profitabilitas perusahaan. Dengan adanya arus kas bebas maka perusahaan memiliki kemampuan untuk membiayai investasi ataupun membayar utang kepada kreditur. Adapun penelitian terhadap pengaruh arus kas bebas terhadap nilai perusahaan telah banyak dilakukan sebelumnya namun masih terdapat inkonsistensi hasil penelitian. Dewi et al. (2019) dan Yuliana (2020) menyatakan bahwa arus kas bebas memiliki pengaruh positif dan signifikan terhadap nilai perusahaan, sedangkan Anggraeni et al. (2018) menyatakan bahwa arus kas bebas memiliki efek negatif signifikan terhadap nilai perusahaan. Disisi lain, Dewi et al. (2018) dan Susilo et al. (2018) menyatakan bahwa arus kas bebas tidak memiliki pengaruh yang signifikan terhadap nilai perusahaan. Dengan masih terdapatnya inkonsistensi hasil penelitian sebelumnya ditambah dengan pentingnya arus kas bebas terhadap nilai perusahaan menurut prinsip manajemen keuangan membuat arus kas bebas menarik untuk diteliti lebih lanjut.

Penelitian terkait nilai perusahaan di Indonesia telah banyak dilakukan sebelumnya. Adapun penelitian terkait nilai perusahaan di Indonesia menggunakan Capital Adequacy Ratio (Murni et al., 2019), Cash On Hand (Toly et al., 2019), Corporate Governance (Toly et al., 2019), CSR (Apriyani \& Sutjahyani, 2018; Tarigan, 2019), Debt To Asset Ratio (Pamungkas \& Maryati, 2017), Debt To Equity Ratio (Murni et al., 2019), Dewan Direksi (Ardianto \& Rivandi, 2018), Dewan Komisaris Independen (Ardianto \& Rivandi, 2018), Economic Value Added (Purnamasari \& Baskara, 2019), ERM (Devi et al., 2017; Ardianto \& Rivandi, 2018; Pamungkas \& Maryati, 2017; Sayilir \& Farhan, 2016; Agustina \& Baroroh, 2016), Leverage (Yuliani et al., 2013; Sudiarto, 2016; Rinnaya et al., 2016; Sartini \& Purbawangsa, 2014; Arizki et al., 2019; Tarigan, 2019; Purnamasari \& Baskara, 2019; Yulianto \& Widyasasi, 2020), Free Cash Flow (Oktaryani \& Mannan, 2018; Dewi et al., 2019; Dewi et al., 2018; Yuliana, 2020; Feriani \& Amanah, 2017; Anggraeni et al., 2018; Susilo et al., 2018), Harga Saham (Yuliana, 2020), Intellectual Capital (Putri \& Nuzula, 2019; Devi et al., 2017; Ardianto \& Rivandi, 2018; Pamungkas \& Maryati, 2017, Investment Opportunity Set (Dewi et al., 2018; Dewi et al., 2019; Anggraeni et al., 2018; Susilo et al., 2018), Islamic Social Reporting (Setiawan et al., 2019), Dividen (Yuliani et al., 2013; Sudiarto, 2016; Sartini \& Purbawangsa, 2014; Ayem \& Tia, 2019; Arizki et al., 2019; Mutmainnah et al., 2019), Investasi (Yuliani et al., 2013; Sudiarto, 2016; Rinnaya et al., 2016; Sartini \& Purbawangsa, 2014; Arizki et al., 2019; Mutmainnah et al., 2019).

Penelitian sebelumnya sebagian besar menggunakan objek perusahaan manufaktur yang tercatat di BEI. Perusahaan manufaktur terdiri atas tiga sektor utama, yaitu Industri Dasar dan Kimia, Aneka Industri, dan Industri Barang Konsumsi. Penelitian ini akan lebih memfokuskan pada salah satu sektor perusahaan manufaktur. Dari Tabel 2 berikut ini terlihat bahwa Sektor Industri Barang Konsumsi memiliki kapitalisasi pasar yang paling tinggi. Dengan demikian, penelitian ini akan memfokuskan objek pada perusahaan Sektor Industri Barang Konsumsi.

Tabel 2 Kapitalisasi Pasar Perusahaan Manufaktur Triwulan I Tahun 2020

\begin{tabular}{clc}
\hline \multirow{2}{*}{ No. } & \multicolumn{1}{c}{ Perusahaan Manufaktur } & Kapitalisasi Pasar (dalam miliar \\
& Rp) \\
\hline 1 & Sektor Industri Dasar dan Kimia & 460.313 \\
2 & Sektor Aneka Industri & 222.422 \\
3 & Sektor Industri Barang Konsumsi & 951.589 \\
\hline
\end{tabular}

Sumber: Diolah dari Laporan Statistik Tahunan BEI Tahun 2019

Selain itu, perusahaan-perusahaan pada Sektor Industri Barang Konsumsi juga memiliki peran yang besar dalam kehidupan masyarakat. Perusahaan barang konsumsi dibutuhkan oleh seluruh lapisan masyarakat. Mulai dari masyarakat yang berpenghasilan rendah hingga para konglomerat. Perusahaan barang konsumsi juga tidak akan tergantikan oleh zaman dan perkembangan teknologi karena secanggih apapun teknologi yang ada, masyarakat tetap membutuhkan barang konsumsi dalam kehidupan sehariharinya. 
Berdasarkan uraian di atas, setidaknya terdapat empat faktor yang diuji dalam penelitian ini untuk menangkap faktor-faktor yang memengaruhi nilai perusahaan, yaitu keputusan pendanaan, keputusan investasi, keputusan dividen dan arus kas bebas. Untuk mengurangi kemungkinan hasil penelitian yang bias, dimasukkan dua variabel kontrol, yaitu ukuran perusahaan dan tingkat profitabilitas yang mewakili ukuran kinerja perusahaan. Dua variabel ini dipilih karena menunjukkan pengaruh yang signifikan dalam penelitian (Rinnaya et al., 2016), (Feriani \& Amanah, 2017), (Dewi et al., 2018) dan (Nurnaningsih \& Herawaty, 2019).

\section{METODOLOGI PENELITIAN}

Metode penelitian yang digunakan dalam penelitian ini adalah metode kuantitatif. Penelitian dengan metode ini dilakukan dengan cara mengumpulkan data kemudian Dalam penelitian ini, nilai perusahaan dipilih sebagai masalah utama dalam penelitian atau objek penelitian. Nilai perusahaan pada penelitian ini dicerminkan melalui Price Book Value (PBV).

Jenis data yang digunakan dalam penelitian ini adalah data sekunder. Data sekunder yang digunakan berupa laporan keuangan perusahaan sektor industri barang konsumsi yang tercatat Bursa Efek Indonesia (BEI) dari tahun 2016 sampai dengan tahun 2019. Data tersebut akan diperoleh dari situs resmi BEI pada https://www.idx.co.id/. Penelitian ini juga menggunakan data panel (pooled data). Populasi dalam penelitian ini adalah perusahaan sektor industri barang konsumsi yang tercatat pada BEI dalam jangka waktu 2016 sampai dengan 2019. Pengambilan sampel dalam penelitian ini dilakukan dengan teknik purposive sampling, yaitu teknik pengambilan sampel yang didasarkan pada kriteria yang telah ditentukan. kriteria pertama adalah perusahaan telah tercatat pada Bursa Efek Indonesia sebelum tanggal 1 Januari 2016. Kedua, perusahaan yang memiliki laporan keuangan dengan informasi lengkap selama tahun 2016 sampai dengan tahun 2019. Total sampel yang digunakan dalam penelitian ini berjumlah 136 observasi.

Variabel dependen dalam penelitian ini adalah nilai perusahaan, sedangkan variabel independen adalah keputusan pendanaan, keputusan investasi, kebijakan dividen dan arus kas bebas. Penelitian ini juga menggunakan variabel kontrol yaitu ukuran perusahaan dan profitabilitas. Dalam penelitian ini nilai perusahaan diukur menggunakan Price to Book Value (PBV) seperti yang dikemukakan oleh Dewi et al. (2019), berbeda dengan Firmansyah \& Purnama (2020), Firmansyah \& Ardi (2020), dan Novianti \& Firmansyah (2020). Purnamasari \& Baskara (2019) menyatakan bahwa PBV merupakan rasio pasar yang digunakan untuk mengukur kinerja harga pasar saham terhadap nilai buku saham. PBV dipilih sebagai rasio untuk mengukur nilai perusahaan karena rasio PBV merupakan rasio yang sering digunakan untuk mengambil keputusan investasi maupun menentukan nilai perusahaan (Tarigan, 2019). Proksi nilai perusahaan dalam penelitian ini mengikuti Dewi et al. (2019) yaitu:

$$
\text { Price to Book Value }=\frac{\text { Harga Pasar Saham per Lembar }}{\text { Nilai Buku per Lembar Saham }}
$$

Harga saham yang digunakan adalah harga saham penutupan (closing price) yaitu harga saham di kuartal terakhir dalam suatu periode pada laporan tahunan yang dipublikasikan di situs resmi BEI sedangkan nilai buku per lembar saham diperoleh dengan cara membagi nilai ekuitas dengan jumlah saham yang beredar. Nilai ekuitas dan juga jumlah saham yang beredar dapat diperoleh dari laporan tahunan yang diterbitkan perusahaan.

Sudiarto (2016) menyatakan bahwa Keputusan pendanaan mencakup cara bagaimana mendanai perusahaan agar operasional maksimal, cara memeroleh investasi yang efisien dan cara mengkomposisikan sumber dana maksimal yang harus dipertahankan. Keputusan pendanaan dalam penelitian ini diukur melalui Debt to Equity Ratio (DER) seperti yang dikemukakan oleh (Tarigan 2019). Sudiarto (2016) mengungkapkan bahwa rasio ini menunjukkan perbandingan antara pembiayaan dan pendanaan melalui utang dengan pendanaan melalui ekuitas, DER yang tinggi memperlihatkan nilai utang yang
Financial Decisions and Company Value 
Financial Decisions and Company Value

besar, dimana utang itu dapat dijadikan modal untuk memutar kegiatan perusahaan untuk mendapatkan laba nantinya akan meningkatkan nilai perusahaan. Pengertian yang tidak jauh berbeda dinyatakan oleh Rinnaya et al. (2016) dimana hasil rasio DER semakin tinggi, maka akan menunjukkan semakin tinggi pendanaan yang disediakan pemegang saham bagi perusahaan dan apabila semakin rendah hasil rasio ini maka akan semakin baik kemampuan perusahaan dalam membayar kewajiban jangka panjangnya. Proksi keputusan pendanaan mengikuti proksi yang digunakan oleh Tarigan (2019) yaitu:

$$
\text { DER }=\frac{\text { Total Utang }}{\text { Total Ekuitas }}
$$

Sudiarto (2016) menyatakan bahwa tujuan keputusan investasi ialah memeroleh tingkat keuntungan yang tinggi dengan tingkat risiko tertentu. Keputusan investasi pada penelitian ini diformulasikan menggunakan Price Earning Ratio (PER) seperti yang dikemukakan oleh (Mutmainnah et al., 2019). PER mengindikasikan besarnya dana yang disetorkan oleh investor untuk memeroleh earning perusahaan. PER merepresentasikan antara harga penutupan saham dibandingkan dengan laba per lembar saham. PER dipilih sebagai proksi pada penelitian ini dikarenakan PER mampu mengindikasikan perusahaan dengan peluang tingkat pertumbuhan tinggi dimana hal ini menunjukkan bahwa pasar mengharapkan pertumbuhan laba di masa mendatang (Prasetyorini, 2013). Proksi keputusan investasi mengikuti Mutmainnah yaitu:

$$
\text { PER }=\frac{\text { Harga Saham }}{\text { Earning per Share }}
$$

Dalam penelitian yang dilakukan oleh Sahputri et al. (2016), kebijakan dividen diukur menggunakan Dividend Per Share (DPS) yaitu jumlah dividen yang dibagikan dibagi dengan jumlah lembar saham yang beredar. Pengukuran kebijakan dividen lainnya menggunakan Dividend Payout Ratio (DPR). Pengukuran ini digunakan oleh Feriani \& Amanah (2017), Oktaryani \& Mannan (2018), Arizki et al. (2019), Tarigan (2019), Mutmainnah et al. (2019) dan Yuliani et al. (2013). Pada penelitian ini proksi yang digunakan adalah DPR seperti yang dikemukakan oleh (Wahyuni \& Mayliza, 2019). Mutmainnah et al. (2019) menyatakan bahwa DPR merupakan rasio pengukuran yang membandingkan antara pembayaran laba perusahaan pada pemegang saham dengan jumlah lembar saham yang dimiliki pada perusahaan. DPR dipilih berdasarkan pertimbangan bahwa DPR lebih populer untuk mengukur persentase dividen tunai yang diberikan perusahaan kepada para pemegang saham dibandingkan dengan rasio dividen lainnya (Feriani \& Amanah, 2017). Proksi kebijakan dividen mengikuti Wahyuni \& Mayliza (2019) yaitu::

$$
D P R=\frac{\text { Dividend per Share }}{\text { Earning per Share }} \times 100 \%
$$

Penelitian ini menggunakan pengukuran arus kas bebas sesuai dengan model yang digunakan (Handayani, 2017). Arus kas bebas akan diukur dengan menggunakan proksi Free Cash Flow (FCF). Adapun FCF dipilih sebagai proksi dikarenakan berdasarkan beberapa penelitian sebelumnya mengenai arus kas bebas, FCF menjadi satu-satunya proksi yang digunakan oleh para peneliti sebelumnya. Perbedaannya hanya dari rumus yang digunakan. Proksi arus kas bebas mengikuti Handayani (2017) yaitu:

$$
F C F=\frac{\text { Laba Bersih Setelah Pajak }- \text { Dividen }+ \text { Penyusutan }}{\text { Total Aktiva }}
$$

Ukuran perusahaan menggambarkan besar kecilnya perusahaan sampel yang dapat dilihat dari kepemilikan aset atau tingkat penjualan perusahaan. Adapun dalam penelitian ini, variabel ukuran perusahaan diukur dengan logaritma natural (ln) dari total aset dengan nilai rupiah penuh sesuai dengan penelitian (Dewi et al., 2018). Penelitian tersebut menyatakan bahwa ukuran perusahaan berpengaruh positif terhadap nilai perusahaan. Artinya, perusahaan yang besar akan mendapat perhatian pihak luar seperti investor dan analis keuangan sehingga akan meningkatkan nilai perusahaan mereka. Proksi ukuran perusahaan mengikuti Dewi et al. (2018) yaitu:

$$
\text { Ukuran perusahaan }(\text { SIZE) = Logaritma (Total Aset) }
$$


Tingkat profitabilitas perusahaan merupakan salah satu aspek yang dapat diamati untuk menilai kinerja suatu perusahaan. Adapun ukuran profitabilitas dalam penelitian ini diukur dengan menggunakan Return on Asset (ROA) seperti yang dikemukakan oleh (Ayem \& Tia, 2019). ROA merupakan rasio yang mengukur tingkat pengembalian laba bersih setelah pajak terhadap total aset. Penelitian yang dilakukan Rinnaya et al. (2016) dan Tarigan (2019) mengungkapkan bahwa profitabilitas perusahaan mempunyai pengaruh positif terhadap nilai perusahaan. Hal ini disebabkan semakin tingginya profit perusahaan, maka harapan dari investor semakin tinggi yang berimplikasi pada naiknya nilai perusahaan. Adapun pengukuran variabel profitabilitas ini mengadopsi dari penelitian Ayem \& Tia (2019) yang diukur dalam rumus sebagai berikut:

\section{Pengembangan Hipotesis}

$$
\text { Return on Asset }(\mathrm{ROA})=\frac{\text { Laba Bersih setelah Pajak }}{\text { Total Aset }}
$$

Berdasarkan teori sinyal, untuk mengurangi adanya asimetri informasi antara manajer dan investor, manajer akan memberikan informasi termasuk informasi yang terkait dengan keputusan pendanaan yang diambil oleh perusahaan. keputusan pendanaan adalah keputusan yang menyangkut penentuan sumber dan bentuk dana untuk pembiayaan. Sumber pembiayaan dapat dibagi menjadi dua yaitu utang dan penerbitan saham. Sumber pembiayaan yang berasal dari utang dapat berasal dari utang jangka pendek maupun utang jangka panjang, sedangkan modal saham dapat terdiri dari saham preferen dan saham biasa. Rinnaya et al. (2016) berpendapat bahwa peningkatan hutang dapat diartikan bahwa perusahaan memiliki kemampuan untuk membayar kewajibannya di masa yang akan datang sehingga penambahan hutang telah memberikan sinyal positif. Apabila pendanaan didanai melalui hutang maka nilai perusahaan akan mengalami kenaikan dikarenakan adanya faktor tax deductible yaitu perusahaan dapat memperhitungkan bunga yang dibayarkan kepada kreditur di dalam penghitungan penghasilan kena pajak yang berimplikasi pada pembayaran pajak yang lebih rendah. Di sisi lain, peningkatan pendanaan melalui laba ditahan ataupun penerbitan saham baru akan membuat perusahaan memiliki risiko keuangan yang lebih kecil dibandingkan dengan penerbitan hutang. Dari uraian di atas, dapat disimpulkan bahwa keputusan pendanaan memiliki pengaruh positif terhadap perusahaan. Mendukung pendapat bahwa keputusan pendanaan memberikan pengaruh positif terhadap nilai perusahaan, penelitian Sartini \& Purbawangsa (2014) dan Rinnaya et al. (2016) menemukan bukti bahwa keputusan pendanaan memiliki pengaruh positif dan signifikan terhadap nilai perusahaan. Berdasarkan uraian tersebut, hipotesis pertama dalam penelitian ini adalah sebagai berikut.

H1: Keputusan pendanaan memiliki pengaruh positif terhadap nilai perusahaan.

Berdasarkan teori sinyal, untuk mengurangi adanya asimetri informasi antara manajer dan investor, manajer akan memberikan informasi termasuk informasi yang terkait dengan keputusan investasi yang diambil oleh perusahaan. Nahdiroh dalam Sartini \& Purbawangsa (2014) menyatakan bahwa keputusan investasi merupakan suatu ketetapan yang dibuat oleh pihak perusahaan dalam membelanjakan dana yang dimilikinya dalam bentuk aset tertentu dengan harapan mendapatkan keuntungan di masa yang akan datang. Informasi terkait keputusan investasi akan memengaruhi keputusan investor dalam menentukan perusahaan yang akan dijadikan wadah investasi. Dengan adanya informasi bahwa perusahaan memiliki keputusan investasi yang baik, maka investor akan tertarik untuk menanamkan modalnya pada perusahaan tersebut.

Rakhimsyah \& Gunawan (2011) mengemukakan bahwa investasi adalah mengorbankan aset yang dimiliki sekarang untuk mendapatkan aset pada masa yang akan datang dengan jumlah yang lebih besar. Dengan kata lain, investasi merupakan salah satu cara untuk memakmurkan para pemegang saham sehingga perusahaan yang mampu berinvestasi secara efisien akan memperoleh kepercayaan dari calon investor. Dengan demikian, semakin tinggi keuntungan yang diperoleh dari investasi, maka semakin tinggi pula nilai perusahaan. Dari uraian di atas, dapat disimpulkan bahwa keputusan investasi memiliki pengaruh positif terhadap perusahaan. Sejalan dengan pendapat sebelumnya,
Financial Decisions and Company Value

\section{9}


Financial Decisions and Company Value penelitian yang dilakukan oleh Dewi et al. (2019) dan Mutmainnah et al. (2019) menyatakan bahwa keputusan investasi memiliki pengaruh positif dan signifikan terhadap nilai perusahaan. Berdasarkan uraian tersebut, hipotesis kedua dalam penelitian ini adalah sebagai berikut

H2 : Keputusan investasi memiliki pengaruh positif terhadap nilai perusahaan.

Berdasarkan teori sinyal, untuk mengurangi adanya asimetri informasi antara manajer dan investor, manajer akan memberikan informasi termasuk informasi yang terkait dengan kebijakan dividen yang diambil oleh perusahaan. Investor perlu mengetahui kebijakan dividen seperti apa yang diambil oleh perusahaan untuk menentukan harapan imbalan hasil yang akan diterima oleh investor. Sinyal informasi yang diberikan akan menentukan penilaian perusahaan oleh investor.

Feriani \& Amanah (2017) mengemukakan bahwa kebijakan dividen merupakan salah satu hal yang dapat menarik investor untuk menanamkan modalnya ke suatu perusahaan. Lebih lanjut Feriani \& Amanah (2017) juga mengemukakan bahwa pembagian laba bersih yang tinggi kepada para pemegang saham dapat membuat investor berlombalomba untuk membeli saham perusahaan tersebut dikarenakan para investor akan menilai bahwa perusahaan memiliki prospek yang baik. Dari uraian di atas, dapat disimpulkan bahwa kebijakan dividen memiliki pengaruh positif terhadap perusahaan. Sesuai dengan pendapat sebelumnya, penelitian yang dilakukan oleh Arizki et al. (2019) dan Mutmainnah et al. (2019) memperoleh hasil bahwa kebijakan dividen memiliki pengaruh positif dan signifikan terhadap nilai perusahaan. Berdasarkan uraian tersebut, hipotesis selanjutnya adalah sebagai berikut.

H3: Kebijakan dividen berpengaruh positif terhadap nilai perusahaan.

Berdasarkan teori sinyal, untuk mengurangi adanya asimetri informasi antara manajer dan investor, manajer akan memberikan informasi termasuk informasi mengenai free cash flow atau arus kas bebas. Informasi ini akan disampaikan ke investor secara eksplisit (laporan keuangan). Informasi mengenai free cash flow akan digunakan untuk pengambilan keputusan oleh para investor. Free cash flow yang tinggi dapat memberikan sinyal positif kepada para pemegang saham bahwa perusahaan mempunyai kinerja yang baik, sehingga hal ini dapat meningkatkan nilai perusahaan. Dari uraian di atas, dapat disimpulkan bahwa arus kas bebas memiliki pengaruh positif terhadap perusahaan. Sesuai dengan pernyataan ini, penelitian yang dilakukan oleh Dewi et al. (2019) dan Yuliana (2020) mendapatkan hasil bahwa free cash flow berpengaruh positif signifikan terhadap nilai perusahaan. Berdasarkan uraian tersebut, hipotesis selanjutnya adalah sebagai berikut.

H4: $\quad$ Arus kas bebas berpengaruh positif terhadap nilai perusahaan.

Model penelitian utama penelitian ini dapat dijabarkan dalam persamaan berikut:

$$
P B V_{i, t}=\alpha_{0}+\alpha_{1} D E R_{i, t}+\alpha_{2} P E R_{i, t}+\alpha_{3} D P R_{i, t}+\alpha_{4} F C F_{i, t}+\alpha_{5} S I Z E_{i, t}+\alpha_{6} R O A_{i, t}+\varepsilon_{i, t}
$$

Keterangan :

$P B V_{i, t}=$ Nilai perusahaan i pada tahun $\mathrm{t}$

$D E R_{i, t}=$ Keputusan pendanaan perusahaan i pada tahun $\mathrm{t}$

$P E R_{i, t}=$ Keputusan investasi perusahaan i pada tahun $\mathrm{t}$

$D P R_{i, t}=$ Kebijakan dividen perusahaan i pada tahun $\mathrm{t}$

$F C F_{i, t}=$ Arus kas bebas perusahaan i pada tahun $\mathrm{t}$

$S I Z E_{i, t}=$ Ukuran perusahaan i pada tahun $\mathrm{t}$

$R O A_{i, t}=$ Return on Asset perusahaan i pada tahun $\mathrm{t}$

$\alpha_{0} \quad=$ Konstanta

$\varepsilon_{i, t} \quad=$ Nilai residu dari persamaan regresi

\section{HASIL DAN PEMBAHASAN}

Statistik deskriptif dalam penelitian ini untuk seluruh variabel adalah sebagai berikut: 
Tabel 3 Statistik Deskriptif

\begin{tabular}{cccccc}
\hline Variabel & Mean & Median & Max. & Min. & Std. Dev. \\
\hline PBV & 5,6149 & 1,8113 & 82,4484 & 0,1777 & 12,2182 \\
DER & 0,7937 & 0,5767 & 3,3389 & 0,0696 & 0,6645 \\
PER & 16,5619 & 15,6129 & 493,548 & $-311,8012$ & 60,896 \\
DPR & 0,3125 & 0,2572 & 1,2435 & 0,0000 & 0,3277 \\
FCF & 0,0612 & 0,0648 & 0,2416 & $-0,1371$ & 0,0589 \\
SIZE & 28,6889 & 28,4863 & 32,2009 & 25,6635 & 1,6451 \\
ROA & 0,0861 & 0,0618 & 0,52670 & $-0,17612$ & 0,1191 \\
\hline
\end{tabular}

Sumber: data diolah

Hasil dari pengujian hipotesis dengan menggunakan fixed effect model adalah sebagai berikut:

Tabel 4 Hasil Uji Hipotesis

\begin{tabular}{crcrr}
\hline Variable & Coefficient & t-Stat. & Prob. & \\
\hline C & 55.359 & 5.6484 & 0.0000 & $* * *$ \\
DER & 0.9386 & 2.7351 & 0.0074 & $* * *$ \\
PER & $-6.12 \mathrm{E}-05$ & -0.2667 & 0.7902 & \\
DPR & -0.6268 & -1.8620 & 0.0657 & $*$ \\
FCF & -8.8117 & -2.9727 & 0.0037 & $* * *$ \\
SIZE & -1.7489 & -5.1814 & 0.0000 & $* * *$ \\
ROA & 4.8962 & 1.3954 & 0.1661 & \\
R2 & & 0.9877 & & \\
Adj. R2 & & 0.9827 & & \\
F-stat. & & 197.6618 & & \\
Prob(F-stat.) & & 0.0000 & &
\end{tabular}

Sumber : data diolah

\section{Pengaruh Keputusan Pendanaan terhadap Nilai Perusahaan}

Hasil penelitian ini menunjukkan bahwa keputusan pendanaan berpengaruh positif terhadap nilai perusahaan. Hasil penelitian ini sejalan dengan penelitian Sartini \& Purbawangsa (2014) dan Rinnaya et al. (2016), namun tidak sejalan dengan Murni et al. (2019). Hasil pengujian dalam penelitian ini mencerminkan bahwa keputusan pendanaan menjadi salah satu pertimbangan investor dalam menanamkan modalnya. Terdapat beberapa alasan mengapa investor menganggap bahwa keputusan pendanaan menjadi sebuah hal yang patut dipertimbangkan dalam berinvestasi pada sebuah perusahaan. Pertama, pendanaan dengan utang memberikan sinyal positif bahwa perusahaan akan melakukan ekspansi bisnis. DER yang tinggi memperlihatkan utang yang besar, dimana utang tersebut dapat dijadikan modal untuk memutar kegiatan perusahaan (Rakhimsyah \& Gunawan, 2011). Kedua, pendanaan dengan utang memberikan sinyal positif bahwa perusahaan memiliki kemampuan untuk membayar kewajibannya di masa yang akan datang. Terdapat kepercayaan diri dari manajemen bahwa mereka dapat berkinerja baik di masa yang akan datang. Ketiga, keputusan pendanaan dengan menitik beratkan pada utang membuat manajer harus bekerja lebih baik dikarenakan utang akan menimbulkan kewajiban di masa yang akan datang yaitu membayar pokok dan bunga atas utang tersebut. Faktor keempat adalah bahwa pembiayaan dengan utang akan menimbulkan beban bunga dimana beban bunga merupakan tax deductible expense yaitu biaya yang dapat mengurangi beban pajak perusahaan. Menggunakan utang sebagai struktur modal perusahaan juga membuat kepemilikan dari investor tidak akan berubah (tidak ada penerbitan saham baru) artinya kepemilikan investor secara prosentase tidak akan berkurang dan perusahaan juga melakukan efisiensi dengan mengurangi jumlah pajak yang harus dibayar.

Financial Decisions and Company Value 
Financial Decisions

and Company

Value

272

\section{Pengaruh Keputusan Investasi terhadap Nilai Perusahaan}

Hasil penelitian ini menunjukkan bahwa keputusan investasi tidak berpengaruh terhadap nilai perusahaan. Hasil dari penelitian ini sejalan dengan penelitian Rinnaya et al. (2016) dan Arizki et al. (2019), namun tidak sejalan dengan Dewi et al. (2019) dan Mutmainnah et al. (2019). Hasil penelitian ini mencerminkan bahwa keputusan investasi tidak dijadikan sebagai salah satu pertimbangan investor dalam menanamkan modalnya. Keputusan investasi tidak dipertimbangkan oleh investor dikarenakan keputusan investasi telah memperhitungkan harga pasar saham dimana harga pasar saham juga telah tercermin pada nilai perusahaan. Investor enggan untuk melakukan double assessment terhadap harga pasar saham sehingga keputusan investasi tidak diperhatikan lagi oleh investor. Alasan lain mengapa keputusan investasi (PER) tidak berpengaruh terhadap nilai perusahaan karena investor mengartikan PER (Price Earning Ratio) secara beragam. Ada yang menganggap PER yang rendah sebagai hal yang positif tetapi ada juga yang menganggap PER yang tinggi merupakan hal yang positif (Gallant, 2020). Oleh karena itu dapat disimpulkan bahwa PER tidak dianggap oleh investor sebagai sinyal, baik itu sebagai "good news" maupun "bad news", yang dapat menunjukkan nilai perusahaan secara tepat.

PER yang rendah mengindikasikan bahwa harga saham perusahaan mengalami undervalued tetapi PER yang rendah juga mengindikasikan akan mengalami pertumbuhan yang lebih lambat dibandingkan dengan perusahaan dengan PER yang lebih tinggi. Di sisi lain, PER yang tinggi mengindikasikan bahwa harga saham perusahaan mengalami overvalued tetapi PER tinggi yang dimiliki oleh perusahaan juga mengindikasikan bahwa perusahaan tersebut memiliki kemampuan untuk tumbuh lebih baik dibandingkan dengan perusahaan dengan PER yang lebih rendah.

\section{Pengaruh Kebijakan Dividen terhadap Nilai Perusahaan}

Hasil penelitian ini menunjukkan bahwa kebijakan dividen berpengaruh negatif terhadap nilai perusahaan. Hasil tersebut mencerminkan bahwa kebijakan dividen tidak dijadikan sebagai salah satu pertimbangan investor dalam menanamkan modalnya. Terdapat beberapa faktor mengapa investor tidak menjadikan kebijakan dividen sebagai pertimbangan dalam menanamkan modalnya. Pertama, tersedianya dana yang ditujukan untuk pembagian dividen memberikan sinyal negatif kepada investor karena hal ini dianggap sebagai inefisiensi perusahaan dalam menggunakan dananya dalam beroperasi. Kedua, investor tidak mengharapkan keuntungan yang berasal dari pembagian dividen, melainkan dari kenaikan harga saham (capital gain). Hal ini sejalan dengan penelitian yang dilakukan oleh Haque et al. (2016) yang menyatakan bahwa kebanyakan investor lebih menyukai capital gain dibandingkan dividen. Faktor ketiga adalah investor menggunakan metode ekuitas dalam menilai investasinya sehingga pembagian dividen akan mengurangi saldo investasi investor.

\section{Pengaruh Arus Kas Bebas terhadap Nilai Perusahaan}

Hasil penelitian ini menunjukkan bahwa arus kas bebas berpengaruh negatif terhadap nilai perusahaan. Hasil penelitian ini sejalan dengan Anggraeni et al. (2018), namun tidak sejalan dengan penelitian Dewi et al. (2019) dan Yuliana (2020). Hasil penelitian ini mencerminkan bahwa arus kas bebas tidak dijadikan sebagai salah satu pertimbangan investor dalam menanamkan modalnya. terdapat beberapa faktor mengapa investor tidak menjadikan arus kas bebas sebagai pertimbangan dalam menanamkan modalnya. Pertama, adanya cash yang idle memberikan sinyal negatif kepada investor bahwa manajemen bingung dalam menggunakan dana yang dimiliki oleh perusahaan. Hal ini sejalan hasil pengujian kebijakan dividen yang dijelaskan sebelumnya. Kedua, investor tidak yakin bahwa adanya free cash yang dimiliki oleh perusahaan akan digunakan untuk membagikan dividen atau digunakan untuk kepentingan lain yang tidak menguntungkan investor. 


\section{PENUTUP}

Keputusan pendanaan yang diproksikan dengan debt to equity ratio berpengaruh positif terhadap nilai perusahaan. Tingginya pendanaan menggunakan utang mendorong nilai perusahaan semakin tinggi. Keputusan investasi tidak berpengaruh terhadap nilai perusahaan, artinya apapun keputusan investasi yang diambil oleh perusahaan, nilai perusahaan tidak akan terpengaruh oleh keputusan investasi tersebut. Selain itu, kebijakan dividen berpengaruh negatif terhadap nilai perusahaan, artinya semakin besar dividen yang dibagikan oleh perusahaan maka nilai perusahaan akan mengalami penurunan. Terakhir, arus kas bebas berpengaruh negatif terhadap nilai perusahaan, artinya semakin besar arus kas bebas yang dimiliki oleh perusahaan maka akan mengurangi nilai perusahaan tersebut.

\section{DAFTAR PUSTAKA}

Agustina, L., \& Baroroh, N. (2016). The relationship between enterprise risk management ( erm) and firm value mediated through the financial performance. Review of Integrative Business and Economics Research, 5(1), 128-138.

Anggraeni, S. B., Paramita, P. D., \& Oemar, A. (2018). Pengaruh free cash flow, risiko bisnis dan investment opportunity set terhadap nilai perusahaan dengan kebijakan hutang sebagai variabel intervening. Journal Of Accounting, 4(4), 1-18.

nggreani, S., \& Adnyana, I. G. S. (2020). Penentuan Harga Pokok Produksi Dengan Metode Full Costing Sebagai Dasar Penetapan Harga Jual Pada UKM Tahu AN Anugrah. Jurnal Ilmiah Akuntansi Kesatuan, 8(1), 9-16.

Apriyani, Y. F., \& Sutjahyani, D. (2018). Pengaruh Corporate Social Responsibility Terhadap Nilai Perusahaan Dengan Profitabilitas Sebagai Variabel Moderating, 3(1), 69-78.

Ardianto, D., \& Rivandi, M. (2018). Pengaruh Enterprise Risk Management Disclosure, Intellectual Capital Disclosure Dan Struktur Pengelolaan Terhadap Nilai Perusahaan. Jurnal Profita, 11(2), 284-305.

Arizki, A., Masdupi, E., \& Zulvia, Y. (2019). Pengaruh Keputusan Investasi, Keputusan Pendanaan dan Kebijakan Dividen terhadap Nilai Perusahaan pada Perusahaan Manufaktur, 1(1), 73-82.

Ayem, S., \& Tia, I. (2019). Pengaruh Perencanaan Pajak, Kebijakan Dividen Dan Kepemilikan Institusional Terhadap Nilai Perusahaan. Jurnal Akuntansi Pajak Dewantara, 1(2), 181-193.

Cahyono, H. S., \& Sulistyawati, A. I. (2016). Keputusan Investasi, Keputusan Pendanaan dan Kebijakan Dividen sebagai Determinan Nilai Perusahaan. Akusisi: Jurnal Akuntansi, 13(1), 39-53.

Devi, S., Budiasih, I. G. N., \& Badera, I. D. N. (2017). Pengaruh Pengungkapan Enterprise Risk Management Dan Pengungkapan Intellectual Capital Terhadap Nilai Perusahaan. Jurnal Akuntansi dan Keuangan Indonesia, 14(1), 20-45.

Dewi, D. K., Tanjung, A. R., \& Indrawati, N. (2018). Analisis Pengaruh Free Cash Flow, Investment Opportunity Set, Ukuran Perusahaan Dan Kepemilikan Manajerial Terhadap Nilai Perusahaan Dengan Kebijakan Hutang Sebagai Variabel Moderating (Studi Pada Perusahaan Manufaktur Yang Listing Di Bursa Efek Indonesia Periode 2012-2016). Jurnal Ekonomi, 26(2), 101-121.

Dewi, I. A. M. C., Sari, M. M. R., Budiasih, I. G. A. N., \& Suprasto, H. B. (2019). Free cash flow effect towards firm value. International Research Journal of Management, IT and Social Sciences, 6(3), 108-116.

Djanegara, M. S., Mulyani, S., Putra, D. M., Zahra, N. A. K., \& Mauludina, M. A. (2018). The effect of institutionalization isomorphic pressures and the role of knowledge management on investment decisions of the accounting information systems. Polish Journal of Management Studies, 18.
Financial Decisions

and Company

Value

273 
Financial Decisions and Company Value
Fenandar, G. I., \& Raharja, S. (2012). Pengaruh Keputusan Investasi, Keputusan Pendanaan, Dan Kebijakan Dividen Terhadap Nilai Perusahaan. Diponegoro Journal of Accounting, 1(2), 1-10.

Feriani, L. Z., \& Amanah, L. (2017). Pengaruh Free Cash Flow Dan Profitabilitas Terhadap Nilai Perusahaan Dengan Kebijakan Dividen Sebagai Variabel Intervening. Jurnal Ilmu dan Riset Akuntansi, 6(12), 1-19.

Firmansyah, A., Ardi, A. K. (2020). Related party transactions, supply chain and cost management on firm's value: evidence from Indonesia. International Journal of Supply Chain Management, 9(3), 1201-1209.

Firmansyah, A., \& Purnama, E. D. P. (2020). Do derivatives instruments ownership decrease firm value in indonesia? Riset Akuntansi dan Keuangan Indonesia, 5(1), 1-9.

Fitania, D. N., \& Firmansyah, A. (2020). The effect of geographic diversification, competition level, and corporate governance on risk disclosure. International Journal of Scientific \& Technology Research, 9(3), 366-372.

Gallant, C. (2020, March 25). Are Stocks With Low P/E Ratios Always Better? Investopedia. https://www.investopedia.com/ask/answers/05/lowperatiostocksbetterinvestmen ts.asp diakses pada 8 Agustus 2020

Handayani, N. L. R. (2017). Pengaruh Stuktur Kepemilikan Institusional Dan Free Cash Flow Terhadap Kebijakan Hutang Dan Nilai Perusahaan. Jurnal Ekonomi \& Bisnis, 3(1), 1-11.

Haque, Dr. R., Fuad, S., \& Mahmud, M. S. (2016). Dividend Versus Capital Gain and Investor Preference: A Case Study on Dhaka Stock Exchange. Available at SSRN 3015985.

Harjito, D. A. (2011). Teori Pecking Order dan Trade-Off dalam Analisis Struktur Modal di Bursa Efek Indonesia. Jurnal Siasat Bisnis, 15(2), 187-196.

Herjanti, S., \& Teg, I. W. T. (2020). Analisis Efektivitas dan Laju Pertumbuhan Pajak Daerah serta Kontribusinya Terhadap Pendapatan Asli Daerah Di Kota Bogor Periode 2013-2017. Jurnal Ilmiah Akuntansi Kesatuan, 8(1), 37-48.

Iriyadi, I., Tartilla, N., \& Gusdiani, R. (2020, May). The Effect of Tax Planning and Use of Assets on Profitability with Good Corporate Governance as a Moderating Variable. In 2nd International Seminar on Business, Economics, Social Science and Technology (ISBEST 2019) (pp. 220-227). Atlantis Press.

Jefriando, M. (2015, December 30). IHSG Merosot 12,81\% Dalam Setahun. https://finance.detik.com/bursa-dan-valas/d-3107878/ihsg-merosot-1281-dalamsetahun diakses pada 8 Agustus 2020

Jumono, S., Abdurrahman, \& Amalia, L. (2013). Deteksi Praktis Aplikasi Pot (Pecking Order Theory). Jurnal Ekonomi Universitas Esa Unggul, 4(1), 17894.

Khairunnisa, N., \& Yuliandi, Y. (2019). Compliance Audit Sebagai Alat Untuk Mendorong Tercapainya Tujuan Organisasi (Studi kasus pada Hotel The 101 Suryakencana Bogor). Jurnal Ilmiah Akuntansi Kesatuan, 7(2), 310-317.

Mahardika, A. G., Pramiudi, U., \& Fahmi, A. (2019). Peranan Penerapan Sistem Akuntansi Accurate Terhadap Penyusunan Laporan Keuangan (Studi Kasus Pada Umkm Toko Textile Leuwi Di Bogor). Jurnal Ilmiah Akuntansi Kesatuan, 7(1), 193 196.

Mudjijah, S., Khalid, Z., \& Astuti, D. A. S. (2019). Pengaruh Kinerja Keuangan Dan Struktur Modal Terhadap Nilai Perusahaan Yang Dimoderasi Variabel Ukuran Perusahaan. Jurnal Akuntansi dan Keuangan, 8(1), 41-56.

Murni, S., Sabijono, H., \& Tulung, J. (2019). The Role of Financial Performance in Determining The Firm Value. Proceedings of the 5th Annual International Conference on Accounting Research (AICAR 2018), 73(5), 66-70.

Mutmainnah, M., Puspitaningtyas, Z., \& Puspita, Y. (2019). Pengaruh Kebijakan Dividen, Keputusan Investasi, Ukuran Perusahaan Dan Kepemilikan Manajerial Terhadap Nilai Perusahaan. Buletin Studi Ekonomi, 24(1), 18-36. 
Novianti, T., \& Firmansyah, A. (2020). The effect of tax risk, hedging, income smoothing, and cash flows volatility on firm value. Test Engineering and Management, 83, 9675 9686.

Nurnaningsih, E., \& Herawaty, V. (2019). Pengaruh Struktur Modal, Profitabilitas, Pertumbuhan Dan Kinerja Keuangan Terhadap Nilai Perusahaan Dengan Kepemilikan Manajerial Sebagai Variabel Moderasi Pada Perusahaan Manufaktur Yang Terdaftar Di Bursa Efek Indonesia Periode 2014-2018. Prosiding Seminar Nasional Cendekiawan, 5(2), 2.42.1-2.42.10.

Oktaryani, G. A. S., \& Mannan, S. S. A. (2018). The Moderating Effect of Dividend Policy on Free Cash Flow and Profitability Towards Firm Value. Jmm Unram - Master Of Management Journal, 7(3), 1-12.

Pamungkas, A. S., \& Maryati, S. (2017). Pengaruh Enterprise Risk Management Disclosure, Intellectual Capital Disclosure Dan Debt To Aset Ratio Terhadap Nilai Perusahaan. Lembaga Penelitian, Pengembangan Pembelajaran \& Pengabdian Kepada Masyarakat, 1(1),412-428.

Pamungkas, B., Flassy, D. A., Yudanto, S., Rachman, H. A., Rahayu, S., Komarudin, S., \& Setijono, H. (2018). Accrual-based accounting implementation in Indonesian's local governments compared to other countries' experiences. Man in India, 98(1), 1-23.

Prasetyorini, B. F. (2013). Pengaruh Ukuran Perusahaan, Leverage, Price Earning Ratio Dan Profitabilitas Terhadap Nilai Perusahaan. Jurnal Imu Manajemen, 1(1), 183-196.

Purnamasari, N. K. P., \& Baskara, I. G. K. (2019). Pengaruh Leverage Profitabilitas dan Economic Value Added pada Nilai Perusahaan Pertambangan di Bursa Efek Indonesia. Jurnal Manajemen dan Kearifan Lokal Indonesia, 3(1), 12-24.

Putri, S. D., \& Nuzula, N. F. (2019). Pengaruh Intellectual Capital Terhadap Kinerja Keuangan Dan Nilai Perusahaan (Studi pada Perusahaan Sektor Manufaktur yang terdaftar di Bursa Efek Indonesia. Jurnal Administrasi Bisnis, 66(1), 28-36.

Rachman, A. N., Rahayu, S. M., \& Topowijono. (2015). Pengaruh Good Corporate Governance Dan Financial Leverage Terhadap Kinerja Keuangan Dan Nilai Perusahaan (Studi Pada Perusahaan Yang Terdaftar Di Indeks Sri Kehati Selama. Jurnal Administrasi Bisnis, 27(1), 1-10.

Rakhimsyah, L. A., \& Gunawan, B. (2011). Pengaruh Keputusan Investasi, Keputusan Pendanaan, Kebijakan Dividen Dan Tingkat Suku Bunga Terhadap Nilai Perusahaan. Jurnal Investasi, 7(1), 31-45.

Rinnaya, I. Y., Andini, R., \& Oemar, A. (2016). Pengaruh Profitabilitas, Rasio Aktivitas, Keputusan Pendanaan Keputusan Investasi Terhadap Nilai Perusahaan (Studi Empiris Pada Perusahaan Manufaktur Yang Terdaftar Di BEI Tahun 2010-2014). Journal Of Accounting, 2(2), 1-18.

Rachman, R. (2019). Analisa Pengendalian Piutang Terhadap Resiko Piutang Tak tertagih Pada PT. Enseval Putera Megatrading Tbk Cabang Bogor. Jurnal Ilmiah Akuntansi Kesatuan, 7(3), 343-350.

Roup, A. (2019). Evaluasi Sistem Informasi Akuntansi Pembelian Dalam Kaitannya Dengan Pengendalian Internal. Jurnal Ilmiah Akuntansi Kesatuan, 7(1), 187-192.

Subagja, R., \& Pradipto, D. (2019). Analisis Penerapan Pengakuan Pendapatan Kontrak Konstruksi Berdasarkan PSAK 34. Jurnal Ilmiah Akuntansi Kesatuan, 7(3), 391-396.

Sahputri, Y., Arfan, M., \& Islahuddin. (2016). Pengaruh Profitabilitas, Likuiditas, dan Free Cash Flow Terhadap Dividen Tunai dan Dampaknya Terhadap Nilai Perusahaan (Studi Pada Perusahaan Perbankan yang Terdaftar di Bursa Efek Indonesia). Jurnal telaah dan Riset Akuntansi, 9(1), 11-18.

Saleh, T. (2018). Kinerja IHSG 2018, Terburuk dalam 3 Tahun. market. https://www.cnbcindonesia.com/market/20181231120250-17-48509/kinerja-ihsg2018-terburuk-dalam-3-tahun diakses pada 8 Agustus 2020

Sartini, L. P. N., \& Purbawangsa, I. B. (2014). Pengaruh Keputusan Investasi, Kebijakan Dividen, Serta Keputusan Pendanaan Terhadap Nilai Perusahaan Manufaktur Di 
Financial Decisions and Company Value
Bursa Efek Indonesia. Jurnal Manajemen, Strategi Bisnis dan Kewirausahaan, 8(2), 8190.

Sayilir, Ö., \& Farhan, M. (2016). Enterprise Risk Management and Its Effect on Firm Value in Turkey. Journal of Management Research, 9(1), 86-99.

Setiawan, I., Swandari, F., \& Dewi, D. M. (2019). Pengaruh Pengungkapan Islamic Social Reporting (Isr) Terhadap Nilai Perusahaan Dengan Kinerja Keuangan Sebagai Variabel Moderating. Jurnal Wawasan Manajemen, 6(2), 168-186.

Sudiarto, R. E. (2016). Pengaruh Keputusan Investasi, Keputusan Pendanaan, Kebijakan Dividen dan tingkat Suku Bunga terhadap Nilai Perusahaan. Skripsi Diterbitkan, Universitas Muhammadiyah Surakarta.

Susilo, H., Dhiana, P., \& Andini, R. (2018). Pengaruh Kepemilikan Institusional, Free Cash Flow, Dan Investment Opportunity Set Terhadap Nilai Perusahaan Dengan Kebijakan Hutang Sebagai Variabel Intervening (Studi Kasus Pada Perusahaan Sektor Keuangan Yang Terdaftar Di BEI Periode 2013-2016). Journal Of Accounting, 4(4), 1-14.

Tarigan, D. (2019). Faktor-Faktor yang Mempengaruhi Nilai Perusahaan Dengan Kebijakan Dividen Sebagai Variabel Moderating pada Perusahaan Manufaktur Sub Sektor Barang Konsumsi yang Terdaftar di Bursa Efek Indonesia Tahun 2012-2017.

Toly, A. A., Claudya, C., Santoso, R., \& Grace, F. (2019). Analisa Pengaruh Corporate Governance, Ownership Structure, dan Cash on Hand Terhadap Nilai Perusahaan. JRKA, 5(2), 31-51.

Wahyuni, I., \& Mayliza, R. (2019). Nilai perusahaan dilihat dari aspek profitabilitas dengan kebijakan deviden sebagai variabel intervening pada perusahaan sektor finance yang terdaftar di Bursa Efek Indonesia. Academic Conference For Management I, 1, 258-273.

Yuliana, T. (2020). Pengaruh Free Cash Flow, Dan Harga Saham Terhadap Nilai Perusahaan Dengan Kebijakan Deviden Sebagai Variabel Intervening. Prosiding Seminar Nasional Pakar, 3(2), 2.46.1-2.24.6.

Yuliani, Isnurhadi, \& Bakar, S. W. (2013). Keputusan Investasi, Pendanaan, Dan Dividen Terhadap Nilai Perusahaan Dengan Risiko Bisnis sebagai Variabel Mediasi. Jurnal Keuangan dan Perbankan, 17(3), 362-375.

Yulianto, \& Widyasasi. (2020). Analisis Faktor-Faktor yang Mempengaruhi Nilai Perusahaan. Jurnal Multiparadigma Akuntansi Tarumanagara, 2(2), 576-585. 